\title{
Enhanced formation of bromate and brominated disinfection byproducts during chlorination of bromide-containing waters under catalysis of copper corrosion products
}

\author{
Jun $\mathrm{Hu}^{\text {a, b }}$, Zhimin Qiang a, b, *, Huiyu Dong a, b, Jiuhui Qu ${ }^{\text {a, b }}$ \\ ${ }^{a}$ Key Laboratory of Drinking Water Science and Technology, Research Center for Eco-Environmental Sciences, Chinese Academy of Sciences, 18 Shuang-qing \\ Road, Beijing 100085, China \\ ${ }^{\mathrm{b}}$ University of Chinese Academy of Sciences, 19 Yu-quan Road, Beijing 100049, China
}

\section{A R T I C L E I N F O}

\section{Article history:}

Received 6 February 2016

Received in revised form

12 April 2016

Accepted 15 April 2016

Available online 19 April 2016

\section{Keywords:}

Copper corrosion products

Catalysis

Bromate

Brominated disinfection byproducts

Water pipe

\begin{abstract}
A B S T R A C T
Copper corrosion products (CCPs) in water distribution pipes may catalyze the reactions among disinfectant, natural organic matter (NOM), and bromide $\left(\mathrm{Br}^{-}\right)$. This study investigated the simultaneous formation of bromate $\left(\mathrm{BrO}_{3}^{-}\right)$and brominated disinfection byproducts (Br-DBPs) during chlorination of $\mathrm{Br}^{-}$-containing waters in the presence of three $\mathrm{CCPs}\left(\mathrm{i} . e ., \mathrm{CuO}_{2} \mathrm{Cu}_{2} \mathrm{O}\right.$, and $\mathrm{Cu}^{2+}$ ). In a synthetic water, both oxidant decay and $\mathrm{BrO}_{3}^{-}$formation were enhanced by CCPs, whereas the presence of humic acid (HA) significantly inhibited $\mathrm{BrO}_{3}^{-}$formation due to its competition for $\mathrm{HOBr}$ to form $\mathrm{Br}$-DBPs. In the $\mathrm{HOCl}-\mathrm{Br}^{-}-\mathrm{CuO}$ system, the $\mathrm{BrO}_{3}^{-}$yield increased obviously with increasing $\mathrm{CuO}$ dose and initial $\mathrm{Br}^{-}$ concentration, while the catalytic formation of $\mathrm{Br}$-DBPs was rather limited. A molar conversion $\left(\mathrm{Br}^{-}\right.$to $\mathrm{BrO}_{3}^{-}$) of $22.1 \%$ was observed under $\mathrm{CuO}$ catalysis, compared with little conversion in the absence of CuO. In the $\mathrm{HOCl}-\mathrm{Br}^{-}-\mathrm{Cu}_{2} \mathrm{O} / \mathrm{Cu}^{2+}$ systems, $\mathrm{Cu}_{2} \mathrm{O}$ or $\mathrm{Cu}^{2+}$ mainly enhanced the formation of $\mathrm{Br}-\mathrm{DBPs}$, with enhancement ratios of $69.9 \%$ and $50.1 \%$, respectively. The degree of enhancement on Br-DBPs formation became more apparent with increasing $\mathrm{pH}$, while that on $\mathrm{BrO}_{3}^{-}$formation reached maximal at $\mathrm{pH}$ 7.6. The catalytic formation of $\mathrm{Br}-\mathrm{DBPs}$ and $\mathrm{BrO}_{3}^{-}$by CCPs was also verified in three filtered real waters, although to a lesser extent because of the water matrix effect. In mechanism, the CCPs promoted the formation of $\mathrm{BrO}_{3}^{-}$and $\mathrm{Br}$-DBPs through catalyzing the $\mathrm{HOBr}$ disproportionation pathway and the reaction of $\mathrm{HOBr}$ toward HA, respectively.
\end{abstract}

() 2016 Elsevier Ltd. All rights reserved.

\section{Introduction}

To maintain the microbial stability in distributed water, chlorine is ubiquitously used as a disinfectant in drinking water distribution systems (Zhang and Andrews, 2012; Liu et al., 2013a). However, one major drawback of chlorinated water treatment is the formation of halogenated disinfection byproducts (DBPs) and other transformation byproducts resulting from the reactions of chlorine with various moieties of water matrix, which has been one of human health concerns over drinking water (Krasner et al., 2006; Heeb et al., 2014).

Natural organic matter (NOM) and bromide $\left(\mathrm{Br}^{-}\right)$are two

\footnotetext{
* Corresponding author. Key Laboratory of Drinking Water Science and Technology, Research Center for Eco-Environmental Sciences, Chinese Academy of Sciences, 18 Shuang-qing Road, Beijing 100085, China.

E-mail address: qiangz@rcees.ac.cn (Z. Qiang).
}

common components of water matrix relevant to oxidation processes (Heeb et al., 2014). $\mathrm{Br}^{-}$can be oxidized to hypobromous acid ( $\mathrm{HOBr})$ by free chlorine $(\mathrm{HOCl})$ with a second-order rate constant of $1.55 \times 10^{3} \mathrm{M}^{-1} \mathrm{~s}^{-1}$, while no further reaction proceeds between $\mathrm{HOCl}$ and $\mathrm{HOBr}$ (Kumar and Margerum, 1987; Beckwith and Margerum, 1997; Margerum and Huff Hartz, 2002). Although the disproportionation of $\mathrm{HOBr}$ still occurs, bromate $\left(\mathrm{BrO}_{3}^{-}\right)$formation during chlorination of $\mathrm{Br}^{-}$-containing waters is usually insignificant because of the slow reaction rate $\left(<10^{-2} \mathrm{M}^{-1} \mathrm{~s}^{-1}\right)$ (Liu et al., 2012). However, $\mathrm{HOBr}$ can react quickly with NOM to form brominated disinfection byproducts (Br-DBPs) (Cowman and Singer, 1996; Richardson et al., 2003; Zhao et al., 2012; Pan and Zhang, 2013), which are more carcinogenic than their chlorinated analogues (Nobukawa and Sanukida, 2000).

Because copper ions can inactivate certain bacterial species (Feng et al., 1996), copper has been extensively used in water distribution pipes throughout the world. The corrosion of copper pipes 
leads to the formation of cupric oxide $(\mathrm{CuO})$ and cuprous oxide $\left(\mathrm{Cu}_{2} \mathrm{O}\right)$ on the inner surface as well as releases copper ions $\left(\mathrm{Cu}^{2+}\right)$ into the drinking water (Li et al., 2007; Xiao et al., 2007; Zhang and Andrews, 2012). Previous studies have reported that these copper corrosion products (CCPs) could catalytically enhance the formation of $\mathrm{BrO}_{3}^{-}$(Liu et al., 2012, 2013a) and halogenated DBPs (Blatchley et al., 2003; Li et al., 2008; Zhang and Andrews, 2012). For example, $\mathrm{CuO}$ could enhance the $\mathrm{BrO}_{3}^{-}$formation during water chlorination via a $\mathrm{CuO}$-catalyzed $\mathrm{HOBr}$ disproportionation pathway as follows (Liu et al., 2012, 2013a):

$3 \mathrm{Br}(\mathrm{I}) \stackrel{\mathrm{CuO}}{\longrightarrow} 2 \mathrm{Br}(-\mathrm{I})+\mathrm{Br}(\mathrm{V})$

where $\mathrm{Br}(\mathrm{I}), \mathrm{Br}(-\mathrm{I})$ and $\mathrm{Br}(\mathrm{V})$ represent $\mathrm{HOBr} / \mathrm{OBr}^{-}, \mathrm{Br}^{-}$, and $\mathrm{BrO}_{3}^{-}$, respectively. Once formed, the $\mathrm{Br}^{-}$could be re-oxidized to $\mathrm{HOBr} /$ $\mathrm{OBr}^{-}$by $\mathrm{HOCl}$, until most of $\mathrm{Br}^{-}$was eventually converted to $\mathrm{BrO}_{3}^{-}$ as long as $\mathrm{HOCl}$ was present in excess. In addition, copper could also catalyze the formation of trihalomethanes (THMs) and haloacetic acids (HAAs) through complexing with precursor compounds to promote the oxidative decarboxylation and enolization of ketogroups (Blatchley et al., 2003; Li et al., 2008). Liu and Croue (2016) investigated the formation of $\mathrm{BrO}_{3}^{-}$and halogenated DBPs in the presence of $\mathrm{CuO}$ during chlorination of six dissolved organic matter isolates, and found that the formation of $\mathrm{THM}_{4}$ and $\mathrm{HAA}_{5}$ was enhanced in simulated distribution systems, particularly for low-SUVA 254 isolates. $\mathrm{BrO}_{3}^{-}, \mathrm{THM}_{4}$ and $\mathrm{HAA}_{5}$ are regulated in drinking water with maximum contaminant levels of 10, 80 and $60 \mu \mathrm{g} \mathrm{L}^{-1}$ by US Environmental Protection Agency (USEPA, 2001), respectively.

This study aimed to investigate the catalysis of three different CCPs (i.e., $\mathrm{CuO}, \mathrm{Cu}_{2} \mathrm{O}$, and $\mathrm{Cu}^{2+}$ ) on the simultaneous formation of $\mathrm{BrO}_{3}^{-}$and $\mathrm{Br}$-DBPs during chlorination of $\mathrm{Br}^{-}$-containing waters. The effects of reaction time, solution $\mathrm{pH}, \mathrm{CCP}$ dose, and initial $\mathrm{Br}^{-}$ concentration on the formation of $\mathrm{BrO}_{3}^{-}$and $\mathrm{Br}$-DBPs were examined in detail. Moreover, three filtered real waters (RWs) were used to evaluate the enhanced formation of $\mathrm{Br}$-DBPs and $\mathrm{BrO}_{3}^{-}$under the catalysis of CCPs. Because copper pipe is commonly used in domestic plumbing systems, understanding the catalysis of CCPs on the formation of $\mathrm{BrO}_{3}^{-}$and $\mathrm{Br}$-DBPs will help water utilities and households to develop the corresponding control strategies.

\section{Materials and methods}

\subsection{Chemicals}

All chemicals used were of analytical grade or higher. The $\mathrm{pH}$ of reaction solution was adjusted by borate buffer $(1 \mathrm{mM})$ and $\mathrm{NaOH} /$ $\mathrm{HNO}_{3}$ solutions. A humic acid (HA) stock solution was prepared by dissolving humic acid solids (Sigma-Aldrich, Shanghai, China) into deionized water and then filtering through $0.45-\mu \mathrm{m}$ membrane filters. Sodium hypochlorite solution ( $\mathrm{NaOCl},>10 \%$ ) was used as the source of chlorine and was periodically standardized. An initial free chlorine concentration of $14.2 \mathrm{mg} \mathrm{L}^{-1}$ (as $\mathrm{Cl}_{2}$ ) was applied to achieve a detectable residual, which was particularly necessary under the catalysis of $\mathrm{Cu}_{2} \mathrm{O}$. $\mathrm{Br}^{-}$was added in the form of potassium bromide. An elevated initial $\mathrm{Br}^{-}$concentration of $2.0 \mathrm{mg} \mathrm{L}^{-1}$ was applied to achieve distinguishable catalytic effects of CCPs on the formation of $\mathrm{BrO}_{3}^{-}$and $\mathrm{Br}-\mathrm{DBPs}$. $\mathrm{Cu}^{2+}$ was added in the form of copper nitrate. $\mathrm{NaOCl}$ solution, potassium bromide, $\mathrm{CuO}, \mathrm{Cu}_{2} \mathrm{O}$, and copper nitrate were all purchased from Sinopharm Chemical Reagent Company (Shanghai, China). The surface areas of $\mathrm{CuO}$ and $\mathrm{Cu}_{2} \mathrm{O}$ were measured to be 4.7 and $11.5 \mathrm{~m}^{2} \mathrm{~g}^{-1}$, respectively, with an ASAP 2020 surface area and porosity analyzer (Micromeritics, USA).

\subsection{Analytical methods}

Residual oxidant (i.e., the sum of $\mathrm{HOCl}$ and $\mathrm{HOBr}$ formed through $\mathrm{Br}^{-}$oxidation by $\mathrm{HOCl}$ ) concentrations were analyzed spectrophotometrically by the $N, N$-diethyl-p-phenylenediamine method at $515 \mathrm{~nm}$ (Rice, 2012). Free bromine (e.g., $\mathrm{HOBr} / \mathrm{OBr}^{-}$) was analyzed according to our earlier developed method (Qiang et al., 2012). $\mathrm{BrO}_{3}^{-}$and $\mathrm{Br}^{-}$were quantified by an ion chromatograph (Dionex-ICS2000) equipped with an Ionpac AS19 column $(250 \mathrm{~mm} \times 4.0 \mathrm{~mm}, 5.0 \mu \mathrm{m})$. KOH solution was used as the eluent with a flow rate of $1.0 \mathrm{~mL} \mathrm{~min}{ }^{-1}$ and a gradient program as follows: $20 \mathrm{mM}$ held for $1 \mathrm{~min}$, and ramped linearly to $110 \mathrm{mM}$ over the next $18 \mathrm{~min}$. The limits of quantification for $\mathrm{Br}^{-}$and $\mathrm{BrO}_{3}^{-}$were 0.5 and $1.0 \mu \mathrm{g} \mathrm{L}^{-1}$, respectively.

The dissolved copper content was determined by an Agilent 7500 inductively coupled plasma mass spectrometer. $\mathrm{Cu}^{+}$concentration was analyzed according to Chen et al. (2015) with certain modifications. In brief, $10 \mathrm{mM}$ ethylenediamine was spiked into a water sample as a masking ligand to inhibit the interference of $\mathrm{Cu}^{2+} ; 1 \mathrm{mM}$ bathocuproine was added to form an orange complex with $\mathrm{Cu}^{+}$; and the orange complex was measured by light absorbance at $484 \mathrm{~nm}$ on a Hach DR6000 spectrophotometer (Hach, USA).

Brominated trihalomethanes (Br-THMs), brominated haloacetic acids (Br-HAAs), and brominated haloacetamides (Br-HAcAms) were extracted according to Bougeard et al. (2010), and then analyzed with a gas chromatograph and an electron capture detector (GC/ECD) (Agilent 7890A) coupled with a DB-5ms separation column $(30 \mathrm{~m} \times 0.25 \mathrm{~mm}, 0.25 \mu \mathrm{m})$. The instrumental conditions for the analysis of Br-THMs and Br-HAcAms were as follows: injection volume of $2.0 \mu \mathrm{L}$ (splitless), helium carrier gas with a flow rate of $2.0 \mathrm{~mL} \mathrm{~min}-1$, injector temperature of $180{ }^{\circ} \mathrm{C}$, detector temperature of $300{ }^{\circ} \mathrm{C}$, and initial oven temperature held at $40{ }^{\circ} \mathrm{C}$ for $5 \mathrm{~min}$, ramped to $45^{\circ} \mathrm{C}$ at $1{ }^{\circ} \mathrm{C} \mathrm{min}{ }^{-1}$ and held for $2 \mathrm{~min}$, ramped to $115^{\circ} \mathrm{C}$ at $10^{\circ} \mathrm{C} \mathrm{min}{ }^{-1}$ and held for $1 \mathrm{~min}$, and finally ramped to $220^{\circ} \mathrm{C}$ at $15^{\circ} \mathrm{C} \mathrm{min}^{-1}$. For the analysis of $\mathrm{Br}$-HAAs, the instrumental conditions were as follows: injector temperature of $210^{\circ} \mathrm{C}$, detector temperature of $300{ }^{\circ} \mathrm{C}$, and initial oven temperature held at $40{ }^{\circ} \mathrm{C}$ for $4 \mathrm{~min}$, and ramped to $80^{\circ} \mathrm{C}$ at $2{ }^{\circ} \mathrm{C} \mathrm{min}^{-1}$. The tested species of $\mathrm{Br}-\mathrm{THMs}, \mathrm{Br}-\mathrm{HAAs}$ and $\mathrm{Br}-\mathrm{HAcAms}$ are described in Text S1.

\subsection{Reaction system}

All experiments were performed in the dark and under magnetic agitation at ambient temperature $\left(25 \pm 2{ }^{\circ} \mathrm{C}\right)$. The reaction bottles $(200 \mathrm{~mL})$ had no headspace and were made chlorine demand free before use. Control experiments were conducted under the same conditions but without the addition of CCPs. Each experiment was performed in duplicate and the relative percent difference (RPD) was calculated.

The effects of reaction time, $\mathrm{pH}, \mathrm{CCP}$ dose, and initial $\mathrm{Br}^{-}$concentration on the catalytic formation of $\mathrm{BrO}_{3}^{-}$and $\mathrm{Br}$-DBPs were investigated systematically. $\mathrm{Cu}^{2+}$ was spiked at concentrations of $0.5,1.0$, and $2.0 \mathrm{mg} \mathrm{L}^{-1}$ because its concentration in water distribution systems could vary from 20 to $2020 \mu \mathrm{g} \mathrm{L}^{-1}$ (Zhang and Andrews, 2012). The doses of $\mathrm{CuO}\left(0.5,1.0\right.$, and $\left.2.0 \mathrm{~g} \mathrm{~L}^{-1}\right)$ and $\mathrm{Cu}_{2} \mathrm{O}\left(0.2,0.5\right.$, and $\left.1.0 \mathrm{~g} \mathrm{~L}^{-1}\right)$ applied in this study were comparable to those adopted by Li et al. (2007). The reaction solution $\mathrm{pH}$ was adjusted to typical $\mathrm{pH}$ values $(6.6,7.6$, and 8.6) in distribution systems. It was observed that the $\mathrm{pH}$ change was insignificant after the reaction. The initial $\mathrm{Br}^{-}$concentration varied from 0.2 to $2.0 \mathrm{mg} \mathrm{L}^{-1}$ when testing its effect on the catalysis of CCPs. After preselected time intervals, water samples were withdrawn, filtered immediately through $0.45-\mu \mathrm{m}$ membrane filters, and analyzed for the residual oxidant. For the analysis of $\mathrm{Br}^{-}, \mathrm{BrO}_{3}^{-}$, and $\mathrm{Br}$-DBPs, the 
residual oxidant was quenched immediately by ascorbic acid. Three different RWs were collected from Danjiangkou Reservoir (DR, Hubei), Miyun Reservoir (MR, Beijing) and Beijing No. 9 Waterworks (NW, Beijing), filtered through $0.45-\mu \mathrm{m}$ membrane filters, and used to evaluate the enhanced formation of $\mathrm{Br}$-DBPs and $\mathrm{BrO}_{3}^{-}$ with various spiked $\mathrm{Br}^{-}$concentrations ( 200 or $500 \mu \mathrm{g} \mathrm{L}^{-1}$ ) in the presence of CCPs. Table S1 shows the major characteristics of these RWs post filtration.

\section{Results and discussion}

\subsection{Oxidant decay and $\mathrm{BrO}_{3}^{-}$formation}

Batch experiments were performed to investigate the oxidant (i.e., $\mathrm{HOCl}+\mathrm{HOBr}$ ) decay and $\mathrm{BrO}_{3}^{-}$formation in the presence and
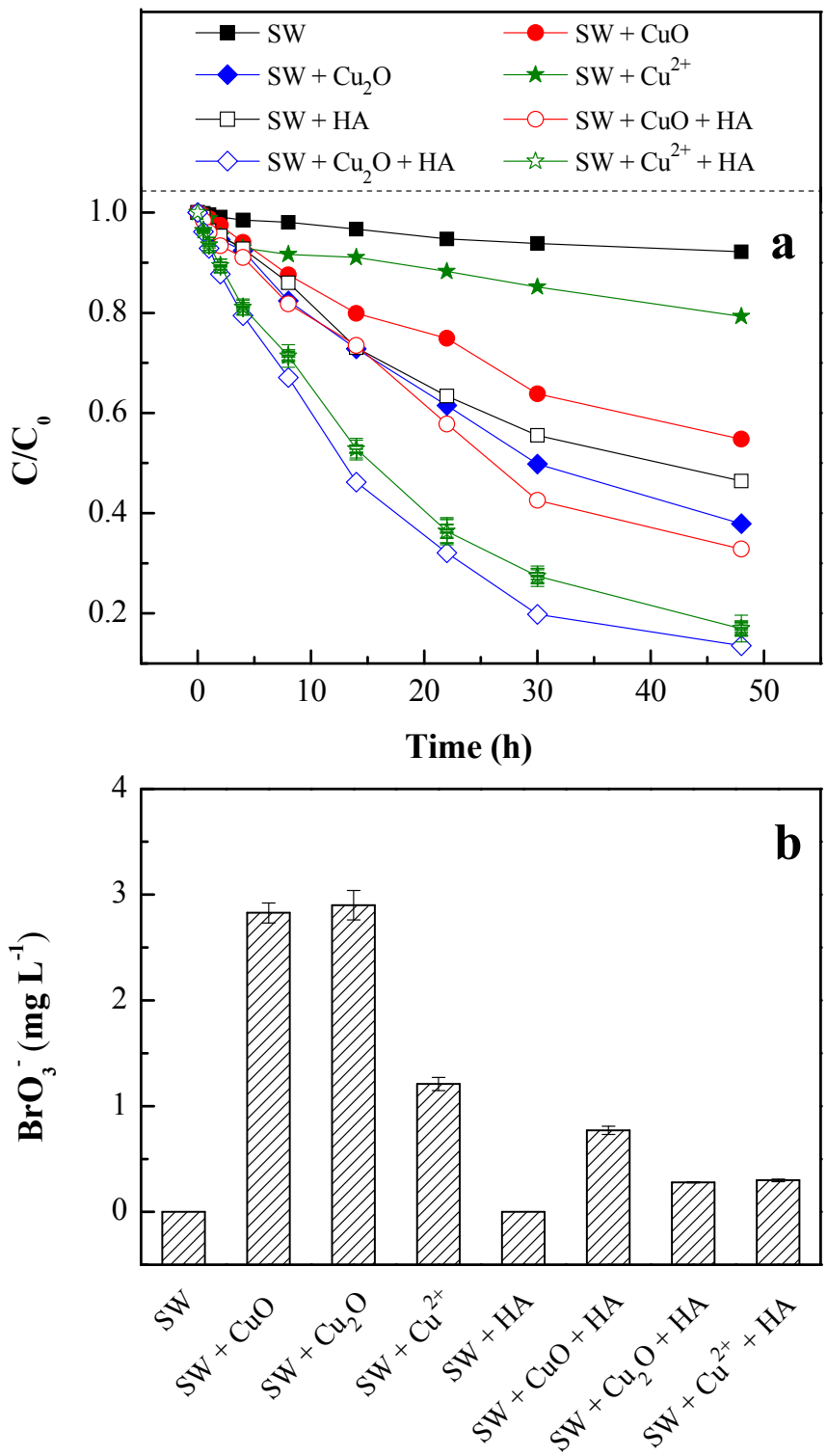

Fig. 1. Oxidant decay (a) and $\mathrm{BrO}_{3}^{-}$formation (b) in the presence or absence of copper corrosion products (CCPs) and humic acid (HA) in the synthetic water (SW). Experimental conditions: $\left[\mathrm{Cl}_{2}\right]_{0}=14.2 \mathrm{mg} \mathrm{L}^{-1}(0.2 \mathrm{mM}),\left[\mathrm{Br}^{-}\right]_{0}=2.0 \mathrm{mg} \mathrm{L}^{-1}(25 \mu \mathrm{M})$, $[\mathrm{HA}]_{0}=5.0 \mathrm{mg} \mathrm{L}^{-1},[\mathrm{CuO}]=2.0 \mathrm{~g} \mathrm{~L}^{-1},\left[\mathrm{Cu}_{2} \mathrm{O}\right]=0.5 \mathrm{~g} \mathrm{~L}^{-1},\left[\mathrm{Cu}^{2+}\right]=2.0 \mathrm{mg} \mathrm{L}^{-1}, \mathrm{pH}=7.6$, reaction time $=48 \mathrm{~h}$. Error bars represent the relative percent differences (RPDs, $n=2$ ). absence of CCPs and HA. As shown in Fig. 1a, the total oxidant concentration remained quite stable in the absence of both CCPs and HA, with a slow pseudo-first-order decay rate of $0.0019 \mathrm{~h}^{-1}$. Only a small amount of oxidants was consumed in the presence of $\mathrm{Cu}^{2+}\left(2.0 \mathrm{mg} \mathrm{L}^{-1}\right)$, whereas the addition of $\mathrm{CuO}\left(2.0 \mathrm{~g} \mathrm{~L}^{-1}\right)$ or $\mathrm{Cu}_{2} \mathrm{O}$ $\left(0.5 \mathrm{~g} \mathrm{~L}^{-1}\right)$ accelerated oxidant decay obviously. The oxidant decay rates were determined to be $0.0134,0.0213$ and $0.0053 \mathrm{~h}^{-1}$ in the presence of $\mathrm{CuO}, \mathrm{Cu}_{2} \mathrm{O}$ and $\mathrm{Cu}^{2+}$, respectively. The released $\mathrm{Cu}^{2+}$ concentrations measured after $72 \mathrm{~h}$ were approximately 0.1 and $0.3 \mathrm{mg} \mathrm{L}^{-1}$ for the solutions containing $2.0 \mathrm{~g} \mathrm{~L}^{-1} \mathrm{CuO}$ and $0.5 \mathrm{~g} \mathrm{~L}^{-1}$ $\mathrm{Cu}_{2} \mathrm{O}$, respectively, indicating that the acceleration of $\mathrm{CuO}$ and $\mathrm{Cu}_{2} \mathrm{O}$ on the oxidant decay was not primarily attributed to the $\mathrm{Cu}^{2+}$ ions released from the copper oxides (Zhang and Andrews, 2012). In addition, after $5.0 \mathrm{mg} \mathrm{L}^{-1} \mathrm{HA}$ was spiked, the oxidant concentration decreased more quickly as expected. It is noted that $\mathrm{Cu}^{2+}$ exhibited a more obvious catalytic impact on the oxidant decay than $\mathrm{CuO}$, which is just opposite to the case in the absence of HA. This is probably due to the different catalytic capabilities of $\mathrm{Cu}^{2+}$ and $\mathrm{CuO}$ on the DBPs formation, which will be discussed later.

Due to the slow oxidant decay, the $\mathrm{BrO}_{3}^{-}$formation in the absence of CCPs and was negligible (Fig. 1b). The presence of CCPs promoted the $\mathrm{BrO}_{3}^{-}$formation at different levels, corresponding to the rates of oxidant decay. After $\mathrm{HA}$ was spiked, the $\mathrm{BrO}_{3}^{-}$formation was suppressed significantly. It was reported that the $\mathrm{HOBr}$ disproportionation rates under $\mathrm{CuO}$ catalysis were 0.5 and $1.6 \mathrm{M}^{-1} \mathrm{~s}^{-1}$ at pHs 6.6 and 7.6, respectively (Liu et al., 2012). The reaction rates of $\mathrm{HOBr}$ with organic compounds are generally greater than $10^{2} \mathrm{M}^{-1} \mathrm{~s}^{-1}$ (Pattison and Davies, 2004; Skaff et al., 2007; Lee and von Gunten, 2009), which are much higher than the $\mathrm{CuO}$-enhanced $\mathrm{HOBr}$ disproportionation rates. Hence, HA could significantly compete for $\mathrm{HOBr}$ to form $\mathrm{Br}$-DBPs, thus exerting an obvious suppression on the $\mathrm{BrO}_{3}^{-}$formation.

\subsection{Time-dependent formation profiles of $\mathrm{Br}-\mathrm{DBPs}$ and $\mathrm{BrO}_{3}$}

To further elucidate the competition between the substitution reaction (to form Br-DBPs) and the disproportionation reaction (to form $\mathrm{BrO}_{3}^{-}$) in the presence of both CCPs and $\mathrm{HA}$, the timedependent formation profiles of $\mathrm{Br}-\mathrm{DBPs}$ and $\mathrm{BrO}_{3}^{-}$were determined. Results indicate that in the absence of CCPs, the yields of $\mathrm{Br}$ THMs and Br-HAAs kept increasing until nearly reaching a plateau after $48 \mathrm{~h}$. By contrast, the Br-HAcAms yield reached the maximum at $24 \mathrm{~h}$ and then gradually decreased (Fig. S1). The initial formation and subsequent degradation of Br-HAcAms could be attributed to the hydrolysis of brominated acetonitriles to form Br-HAcAms, which could further hydrolyze to produce Br-HAAs (Chu et al., 2012). The presence of CCPs facilitated the formation of Br-DBPs to different extents. As shown in Fig. 2a, with the spike of $\mathrm{Cu}_{2} \mathrm{O}$ and $\mathrm{Cu}^{2+}$, the enhancement ratios on Br-DBPs formation reached $69.9 \%$ and $50.1 \%$ after $72 \mathrm{~h}$, respectively. However, CuO could only slightly enhance the Br-DBPs formation. This result is consistent with the oxidant decay rates in the presence of HA mentioned above.

Being different from the quick formation of Br-DBPs, a lag phase appeared for the $\mathrm{BrO}_{3}^{-}$formation within the first several hours (Fig. 2b). The $\mathrm{HOBr}$ disproportionation pathway consists of two steps to produce $\mathrm{BrO}_{3}^{-}$, through a decisive intermediate, $\mathrm{Br}(\mathrm{III})$ (i.e., $\mathrm{BrO}_{2}^{-}$) (Beckwith and Margerum, 1997):

$\mathrm{Br}(\mathrm{I})+\mathrm{Br}(\mathrm{I}) \rightarrow \mathrm{Br}(\mathrm{III})+\mathrm{Br}(-\mathrm{I}), \quad k=2 \times 10^{-3} \mathrm{M}^{-1} \mathrm{~s}^{-1}$

$\mathrm{Br}(\mathrm{I})+\mathrm{Br}(\mathrm{III}) \rightarrow \mathrm{Br}(\mathrm{V})+\mathrm{Br}(-\mathrm{I})$, much faster

It is seen that the production of $\mathrm{BrO}_{2}^{-}$is a rate-limiting step. Hence, the reaction between $\mathrm{HOBr}$ and highly reactive $\mathrm{HA}$ moieties 


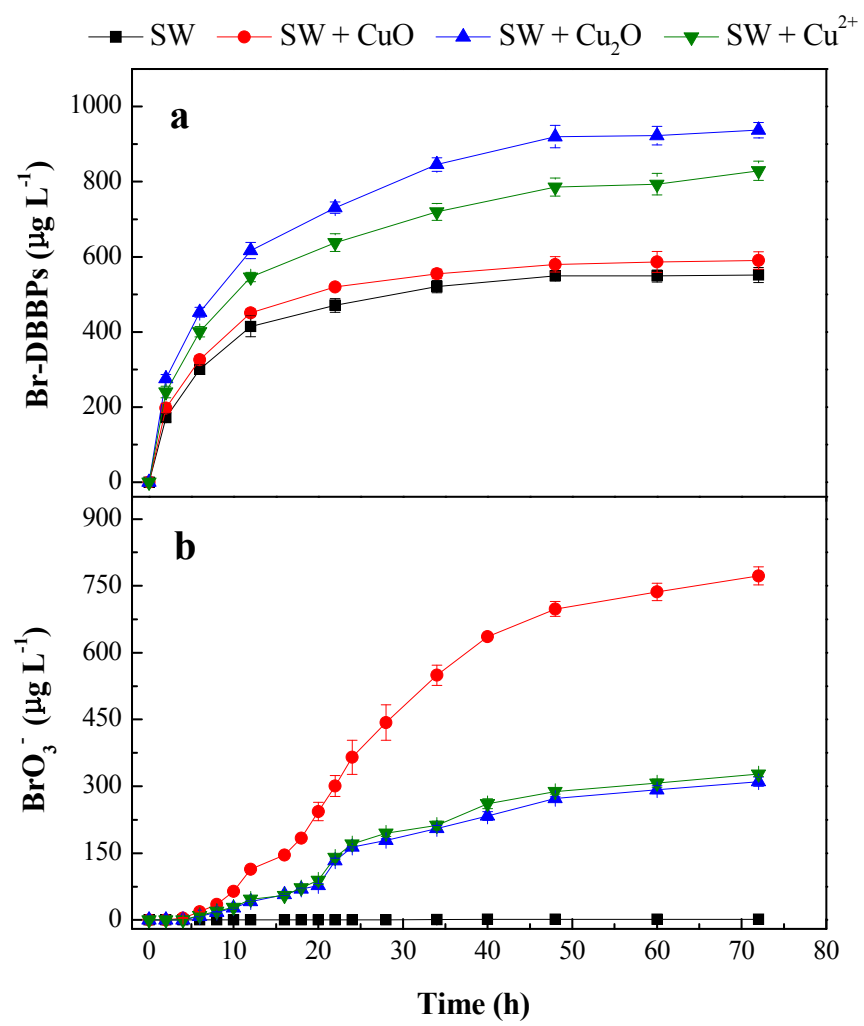

Fig. 2. Time-dependent formation of $\mathrm{Br}-\mathrm{DBPs}(\mathrm{a})$ and $\mathrm{BrO}_{3}^{-}$(b) in the presence of CCPs and $\mathrm{HA}$ in the SW. Experimental conditions: $\left[\mathrm{Cl}_{2}\right]_{0}=14.2 \mathrm{mg} \mathrm{L}^{-1},\left[\mathrm{Br}^{-}\right]_{0}=2.0 \mathrm{mg} \mathrm{L}^{-1}$, $[\mathrm{HA}]_{0}=5.0 \mathrm{mg} \mathrm{L}^{-1},[\mathrm{CuO}]=2.0 \mathrm{~g} \mathrm{~L}^{-1},\left[\mathrm{Cu}_{2} \mathrm{O}\right]=0.5 \mathrm{~g} \mathrm{~L}^{-1},\left[\mathrm{Cu}^{2+}\right]=2.0 \mathrm{mg} \mathrm{L}^{-1}, \mathrm{pH}=7.6$. Error bars represent the RPDs $(n=2)$.

could suppress the $\mathrm{BrO}_{2}^{-}$formation and result in the lag phase for the $\mathrm{BrO}_{3}^{-}$formation. Only after the highly reactive $\mathrm{HA}$ moieties were substantially consumed by $\mathrm{HOBr}$ (i.e., after $10 \mathrm{~h}$ ) did $\mathrm{BrO}_{3}^{-}$start to be formed quickly.

According to previous studies (Alvarez-Puebla et al., 2004; Deborde and von Gunten, 2008), $\mathrm{Cu}^{2+}$ could complex with the carbonyl and hydroxyl groups of NOM, thus facilitating the basecatalyzed enolization and hydrolysis reactions. Recently, Chen et al. (2015) found that $\mathrm{Cu}^{2+}$ was not merely a hydrolysis catalyst but also an oxidant for the transformation of benzylpenicillin in oxygen-rich aqueous solutions. The degradation of benzylpenicillin involved the oxidation by $\mathrm{Cu}^{2+}$ through $\mathrm{Cu}^{+} . \mathrm{Cu}^{2+}$ could be regenerated via the oxidation of $\mathrm{Cu}^{+}$by dissolved oxygen (DO) with a short half-life of less than $1 \mathrm{~min}$ in freshwater (Pham et al., 2012), which sustained the continuous degradation of benzylpenicillin. Hence, $\mathrm{Cu}^{2+}$ may also activate certain HA fractions to induce a higher reaction rate between $\mathrm{HOBr}$ and $\mathrm{HA}$. In this study, $\mathrm{Cu}^{+}$was measured only at a very low concentration level in the $\mathrm{HOCl}-\mathrm{Br}^{-}-\mathrm{Cu}^{2+}$ system (Fig. S2). A possible explanation is that the standard oxidation-reduction potential of chlorine $\left(E_{\mathrm{Cl}_{2} / \mathrm{Cl}^{-}}^{\circ}=1.36 \mathrm{~V}\right)$ is much higher than that of $\mathrm{DO}$ $\left(E_{\mathrm{O}_{2} / \mathrm{OH}^{-}}^{\circ}=0.4 \mathrm{~V}\right)$, so chlorine can more easily convert $\mathrm{Cu}^{+}$to $\mathrm{Cu}^{2+}$. As for the copper oxides (i.e., $\mathrm{CuO}$ and $\mathrm{Cu}_{2} \mathrm{O}$ ), heterogeneous reactions could occur. Gallard et al. (2009) reported that the iodine species (i.e., $\mathrm{HOI}$ and $\mathrm{I}_{2}$ ) were catalytically converted to iodinated organic byproducts on the surface of $\delta-\mathrm{MnO}_{2}$. Likewise, the bromine in $\mathrm{HOBr} / \mathrm{OBr}^{-}$could also be polarized by $\mathrm{CuO} / \mathrm{Cu}_{2} \mathrm{O}$ (Lewis acids) to increase its reactivity toward $\mathrm{HA}$.

In summary, the $\mathrm{BrO}_{3}^{-}$formation was primarily promoted in the $\mathrm{HOCl}-\mathrm{Br}^{-}-\mathrm{CuO}$ system, whereas the formation of studied Br-DBPs (i.e., the sum of Br-THMs, Br-HAAs, and Br-HAcAms) was primarily promoted in the $\mathrm{HOCl}-\mathrm{Br}^{-}-\mathrm{Cu}_{2} \mathrm{O}$ and $\mathrm{HOCl}-\mathrm{Br}^{-}-\mathrm{Cu}^{2+}$ systems. Fig. 3 shows the bromine mass balance in the absence or presence of CCPs. Results indicate that without the addition of CCPs, $0.04 \%$ and $24.6 \%$ of $\mathrm{Br}^{-}$(on a molar basis) were converted to $\mathrm{BrO}_{3}^{-}$and the studied $\mathrm{Br}$-DBPs, respectively. By contrast, the conversion ratios of $\mathrm{Br}^{-}$to $\mathrm{BrO}_{3}^{-}$increased to $22.1 \%, 8.6 \%$ and $9.1 \%$ in the presence of $\mathrm{CuO}, \mathrm{Cu}_{2} \mathrm{O}$ and $\mathrm{Cu}^{2+}$, respectively; and meanwhile, the conversion ratios of $\mathrm{Br}^{-}$to the studied $\mathrm{Br}$-DBPs reached $24.7 \%, 36.0 \%$ and $30.6 \%$, correspondingly. It is also noted that a considerable amount of bromide (29.7-44.9\%) was incorporated in organic byproducts which could not be identified (i.e., unknown Br-DBPs).

\subsection{Effect of $\mathrm{pH}$}

The effect of $\mathrm{pH}$ on the catalytic formation of $\mathrm{Br}-\mathrm{DBPs}$ and $\mathrm{BrO}_{3}^{-}$ was tested in the $\mathrm{pH}$ range of 6.6-8.6. As shown in Fig. S3, without the addition of CCPs, the formation of Br-THMs and Br-HAAs decreased with increasing $\mathrm{pH}$, while the Br-HAcAms formation maximized at $\mathrm{pH}$ 7.6. Chu et al. (2012) found that the difference between the hydrolysis rates of dichloroacetonitrile and dichloroacetamide at $\mathrm{pH}$ 7.0-8.0 was higher than those at other $\mathrm{pH}$ levels. In the presence of $\mathrm{Cu}^{2+}$, the catalytic formation of Br-DBPs was notably dependent on $\mathrm{pH}$, and the degree of enhancement became more apparent at a higher $\mathrm{pH}$ (Fig. 4a). A previous study reported that the $\mathrm{Cu}^{2+}$-catalyzed enolization and hydrolysis of NOM were accelerated with increasing pH (Deborde and von Gunten, 2008). Furthermore, the deprotonation of NOM functional groups (e.g., carboxyl and hydroxyl groups), which is more favorable at a higher $\mathrm{pH}$, may make electron transfer to $\mathrm{Cu}^{2+}$ easier, leading to the reduction of $\mathrm{Cu}^{2+}$ to $\mathrm{Cu}^{+}$and the concurrent oxidation of NOM. The catalytic promotion of $\mathrm{CuO} / \mathrm{Cu}_{2} \mathrm{O}$ on the $\mathrm{Br}$-DBPs formation showed a similar tendency with increasing $\mathrm{pH}$. One possible explanation is that the deprotonation of $\mathrm{HOBr}$ to $\mathrm{OBr}^{-}$favored the electrostatic interactions with the positively charged $\mathrm{CuO} / \mathrm{Cu}_{2} \mathrm{O}$ surface (Liu et al., 2012), thus comparatively enhancing the Br-DBPs formation.

In Fig. $4 \mathrm{~b}$, the trend of $\mathrm{BrO}_{3}^{-}$formation was similar for each of the three catalysts, which maximized at $\mathrm{pH}$ 7.6. However, Liu et al. (2012) reported that the $\mathrm{BrO}_{3}^{-}$yield reached the maximum at $\mathrm{pH}$ 8.6 in the $\mathrm{HOBr}-\mathrm{CuO}$ system. The difference lies in the fact that the reaction in this study was initiated by $\mathrm{HOCl}$, which was present in large excess of $\mathrm{Br}^{-}$. At pHs 6.6 and 7.6, $\mathrm{Br}^{-}$was quickly oxidized to $\mathrm{HOBr}$ so that the $\mathrm{BrO}_{3}^{-}$formation was facilitated. According to the conceptual model proposed by Liu et al. (2012), the rate constant estimated for the $\mathrm{CuO}-\mathrm{OBr}^{-}$complex reacting with $\mathrm{HOBr}$ was two orders of magnitude higher than that estimated for the $\mathrm{CuO}-\mathrm{HOBr}$ complex. Thus, the $\mathrm{CCP}-\mathrm{OBr}^{-}$complex was also likely to react with $\mathrm{HOBr}$ more quickly for $\mathrm{BrO}_{3}^{-}$formation at $\mathrm{pH} 7.6$ than at $\mathrm{pH}$ 6.6.

\subsection{Effect of CCP dose}

The effect of CCP dose on the catalytic formation of Br-DBPs and $\mathrm{BrO}_{3}^{-}$is manifested in Fig. S4. Results indicate that as the CCP dose increased, the formation of Br-HAAs and Br-HAcAms was slightly enhanced, whereas a significant enhancement on the Br-THMs formation was observed. The CCPs played a catalytic role through complexation with HA, thus the formation of Br-DBPs was generally enhanced with increasing CCP dose. On the whole, the formation of Br-DBPs was considerably affected by the doses of $\mathrm{Cu}_{2} \mathrm{O}$ and $\mathrm{Cu}^{2+}$, while only changed slightly with increasing $\mathrm{CuO}$ dose (Fig. 5). Analogously, the $\mathrm{BrO}_{3}^{-}$formation was also enhanced with increasing CCP doses because of the availability of more reactive sites (or ions) interacting with $\mathrm{HOBr} / \mathrm{OBr}^{-}$. Nevertheless, the $\mathrm{BrO}_{3}^{-}$ yield was affected by the $\mathrm{CuO}$ dose more significantly than by the doses of $\mathrm{Cu}_{2} \mathrm{O}$ and $\mathrm{Cu}^{2+}$ (Fig. 5). The results further confirm that $\mathrm{BrO}_{3}^{-}$formation was primarily promoted in the $\mathrm{HOCl}-\mathrm{Br}^{-}-\mathrm{CuO}$ 

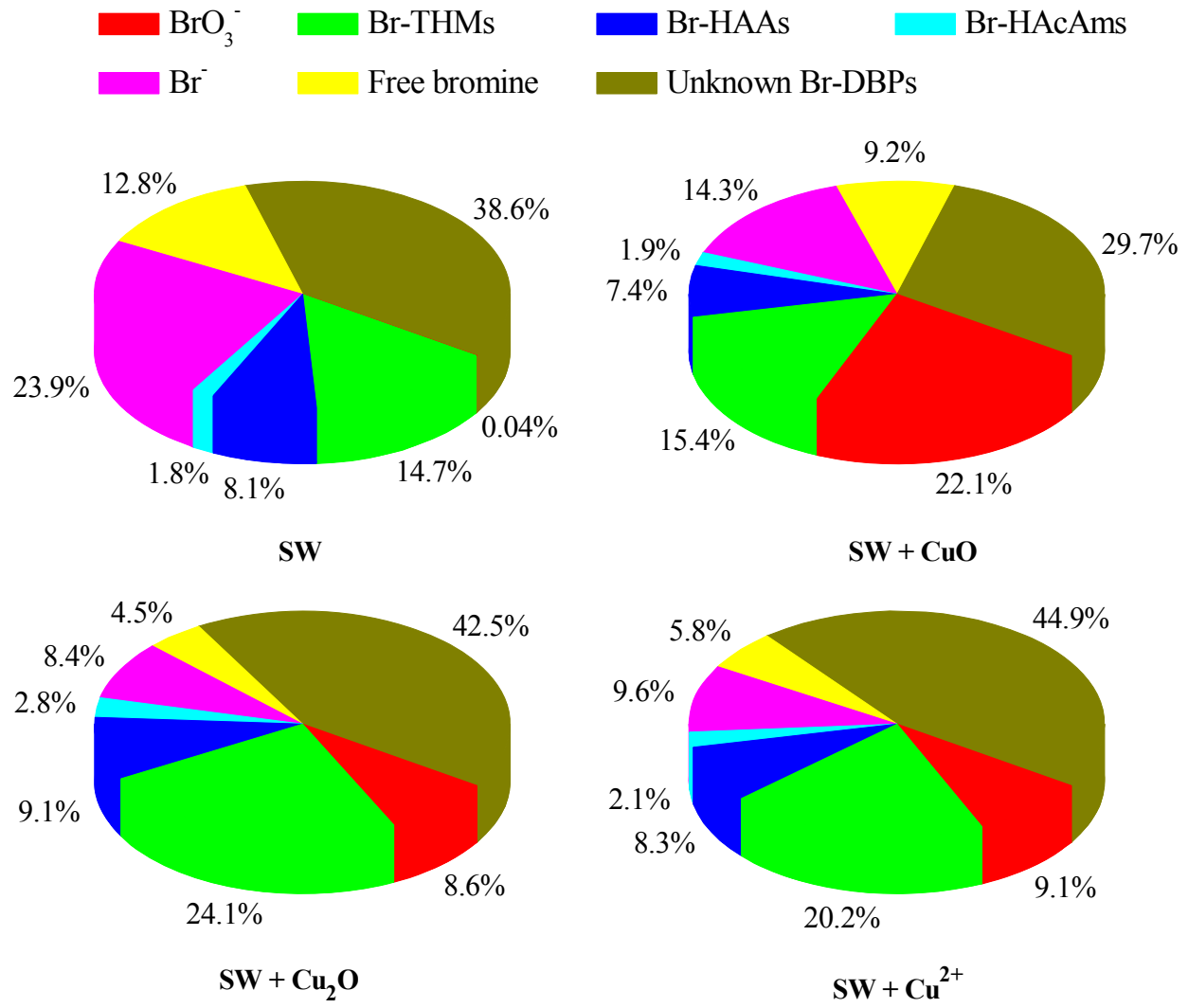

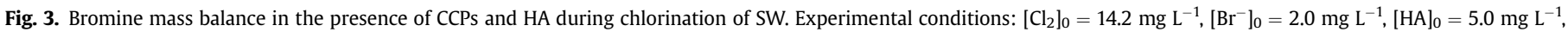
$[\mathrm{CuO}]=2.0 \mathrm{~g} \mathrm{~L}^{-1},\left[\mathrm{Cu}_{2} \mathrm{O}\right]=0.5 \mathrm{~g} \mathrm{~L}^{-1},\left[\mathrm{Cu}^{2+}\right]=2.0 \mathrm{mg} \mathrm{L}^{-1}, \mathrm{pH}=7.6$, reaction time $=72 \mathrm{~h}$.

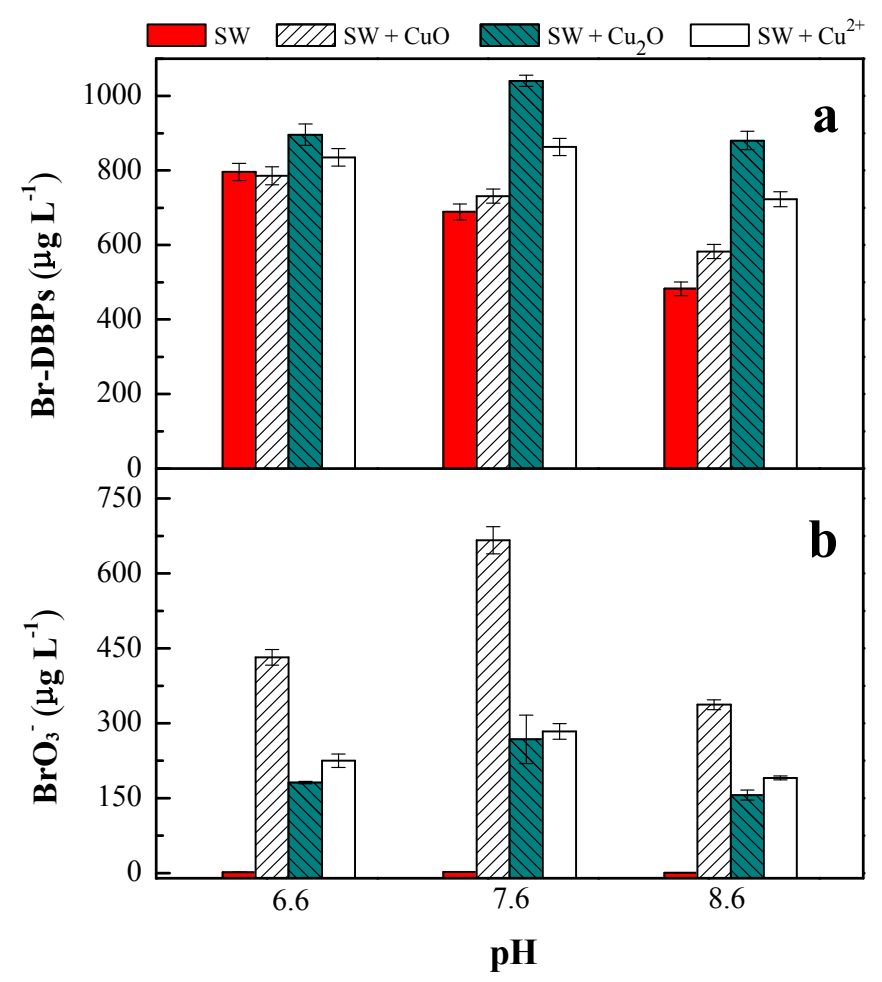

Fig. 4. Effect of $\mathrm{pH}$ on the catalytic formation of $\mathrm{Br}-\mathrm{DBPs}(\mathrm{a})$ and $\mathrm{BrO}_{3}^{-}$(b) in the SW. Experimental conditions: $\left[\mathrm{Cl}_{2}\right]_{0}=14.2 \mathrm{mg} \mathrm{L}^{-1},\left[\mathrm{Br}^{-}\right]_{0}=2.0 \mathrm{mg} \mathrm{L}^{-1},[\mathrm{HA}]_{0}=5.0 \mathrm{mg} \mathrm{L}^{-1}$, $[\mathrm{CuO}]=2.0 \mathrm{~g} \mathrm{~L}^{-1},\left[\mathrm{Cu}_{2} \mathrm{O}\right]=0.5 \mathrm{~g} \mathrm{~L}^{-1},\left[\mathrm{Cu}^{2+}\right]=2.0 \mathrm{mg} \mathrm{L}^{-1}$, reaction time $=72 \mathrm{~h}$. Error bars represent the RPDs $(n=2)$. system, whereas Br-DBPs formation was primarily promoted in the $\mathrm{HOCl}-\mathrm{Br}^{-}-\mathrm{Cu}_{2} \mathrm{O}$ and $\mathrm{HOCl}-\mathrm{Br}^{-}-\mathrm{Cu}^{2+}$ systems.

\subsection{Effect of initial $\mathrm{Br}^{-}$concentration}

Bromine utilization factor (BUF) and bromine incorporation factor (BIF) were calculated to examine the effect of initial $\mathrm{Br}^{-}$ concentration on the catalytic formation of Br-DBPs. BUF refers to the percentage of $\mathrm{Br}^{-}$that is utilized in forming Br-DBPs, and BIF is used as an index to describe the proportion of Br-DBPs that is partially or totally substituted by bromine. The equations used to calculate the BUF and BIF values are shown in Text S2. The BUF values range from 0 to 1 . For example, a BUF value of 0.5 for $\mathrm{Br}$ THMs indicates that half of $\mathrm{Br}^{-}$was utilized to produce Br-THMs. The BIF values range from 0 (all chlorinated DBPs) to 3 (all $\mathrm{Br}$ DBPs). For example, a BIF value of 2 for THMs means that the typical THM species is dibromochloromethane on average.

As expected, no matter whether CCPs were present or absent, the formation of Br-DBPs always increased with increasing $\mathrm{Br}^{-}$ concentration (Fig. 6a). The specific formation of Br-THMs, Br-HAAs and Br-HAcAms is presented in Fig. S5. The BIFs exhibited a similar trend as well. However, the BUFs decreased with increasing $\mathrm{Br}^{-}$ concentration. For example, when the $\mathrm{Br}^{-}$concentration increased from 0.2 to $2.0 \mathrm{mg} \mathrm{L}^{-1}$, the Br-THMs formation increased from 276.6 to $638.4 \mathrm{~g} \mathrm{~L}^{-1}$, and the BIF for Br-THMs increased from 0.52 to 2.20, while the BUF for Br-THMs decreased from 0.40 to 0.26 in the presence of $\mathrm{Cu}_{2} \mathrm{O}$, respectively. The increased BIF implies that there was more bromine incorporated into tribromomethane with increasing $\mathrm{Br}^{-}$concentration, while the decreased BUF implies that the utilized $\mathrm{Br}^{-}$in forming $\mathrm{Br}$-THMs did not increase in proportion to the initial $\mathrm{Br}^{-}$concentration. 

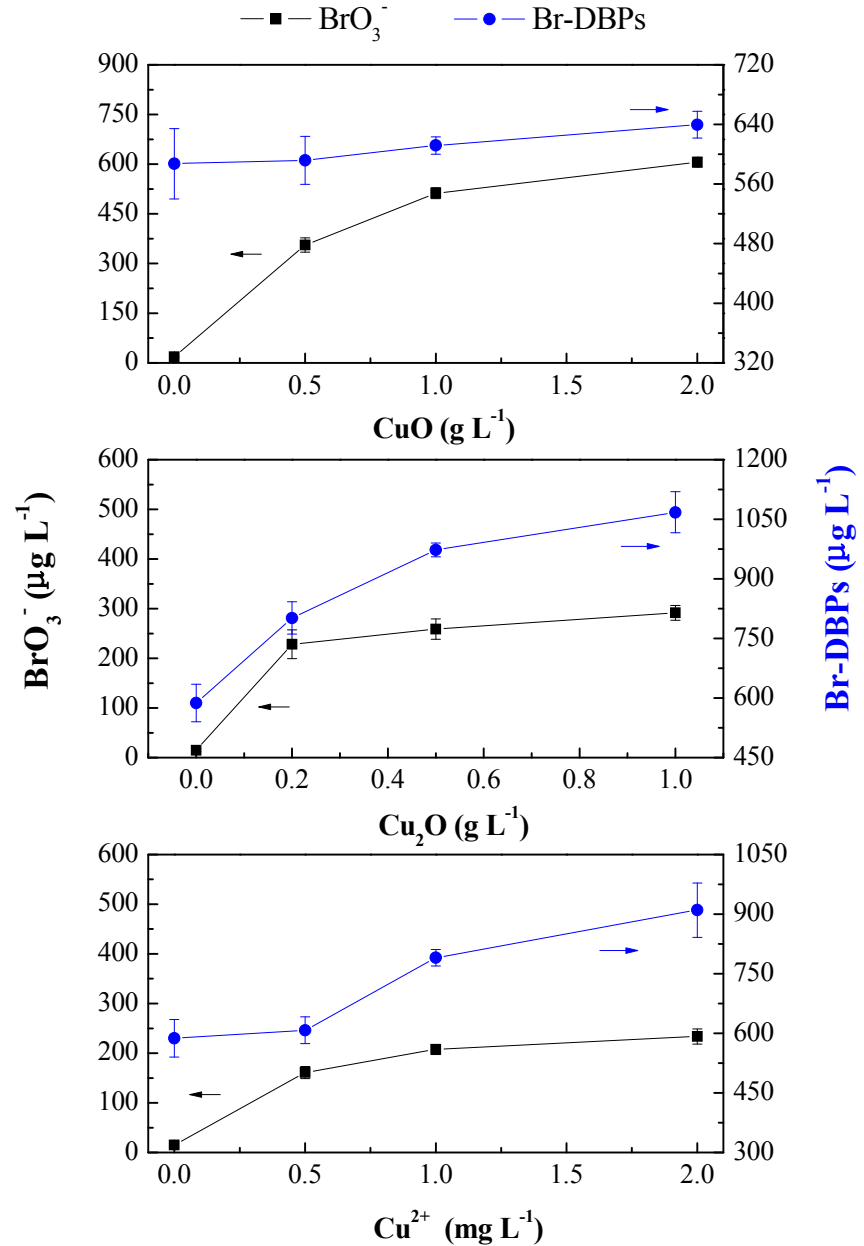

Fig. 5. Effect of CCP dose on the catalytic formation of $\mathrm{Br}-\mathrm{DBPs}$ and $\mathrm{BrO}_{3}^{-}$in the SW. Experimental conditions: $\left[\mathrm{Cl}_{2}\right]_{0}=14.2 \mathrm{mg} \mathrm{L}^{-1},\left[\mathrm{Br}^{-}\right]_{0}=2.0 \mathrm{mg} \mathrm{L}^{-1},[\mathrm{HA}]_{0}=5.0 \mathrm{mg} \mathrm{L}^{-1}$, $\mathrm{pH}=7.6$, reaction time $=72 \mathrm{~h}$. Error bars represent the RPDs $(n=2)$.

In addition, the $\mathrm{BrO}_{3}^{-}$formation was also enhanced with increasing $\mathrm{Br}^{-}$concentration (Fig. 6b). For example, as the $\mathrm{Br}^{-}$ concentration increased from 0.2 to $2.0 \mathrm{mg} \mathrm{L}^{-1}$, the $\mathrm{BrO}_{3}^{-}$yield increased from 14.2 to $616.2 \mu \mathrm{g} \mathrm{L}^{-1}$ in the presence of $\mathrm{CuO}$. Due to a significant competition from $\mathrm{HA}$, the majority of $\mathrm{HOBr} / \mathrm{OBr}^{-}$was converted to Br-DBPs at low $\mathrm{Br}^{-}$concentrations. However, at a high $\mathrm{Br}^{-}$concentration, the excessive $\mathrm{HOBr} / \mathrm{OBr}^{-}$could be transformed to $\mathrm{BrO}_{3}^{-}$via the disproportionation pathway under the catalysis of CCPs.

\subsection{Effect of real water characteristics}

Three different RWs (i.e., MR, DR and NW) were used post filtration to evaluate the effect of water matrix on the catalytic formation of $\mathrm{Br}-\mathrm{DBPs}$ and $\mathrm{BrO}_{3}^{-}$. As shown in Fig. S6, although the CCPs catalytically enhanced the formation of Br-THMs, Br-HAAs and $\mathrm{Br}-\mathrm{HAcAms}$ in the RWs, the degree of enhancement were relatively lower than that in the SW. For an instance, at the $\mathrm{Br}^{-}$concentrations of $0.5 \mathrm{mg} \mathrm{L}^{-1}$, the enhancement ratios on Br-DBPs formation under $\mathrm{Cu}_{2} \mathrm{O}$ catalysis were $47.4 \%$ and $60 \%$ in the MR water and $\mathrm{SW}$, respectively (Fig. 7a). The $\mathrm{BrO}_{3}^{-}$formation presented a similar trend. For example, at the $\mathrm{Br}^{-}$concentration of $0.5 \mathrm{mg} \mathrm{L}^{-1}$, the $\mathrm{BrO}_{3}^{-}$ concentrations under $\mathrm{CuO}$ catalysis were 37.3 and $80.5 \mu \mathrm{g} \mathrm{L}^{-1}$ in the MR water and SW, respectively (Fig. 7b). Despite of the similar SUVA $_{254}$ values of the three RWs, the dissolved organic carbon

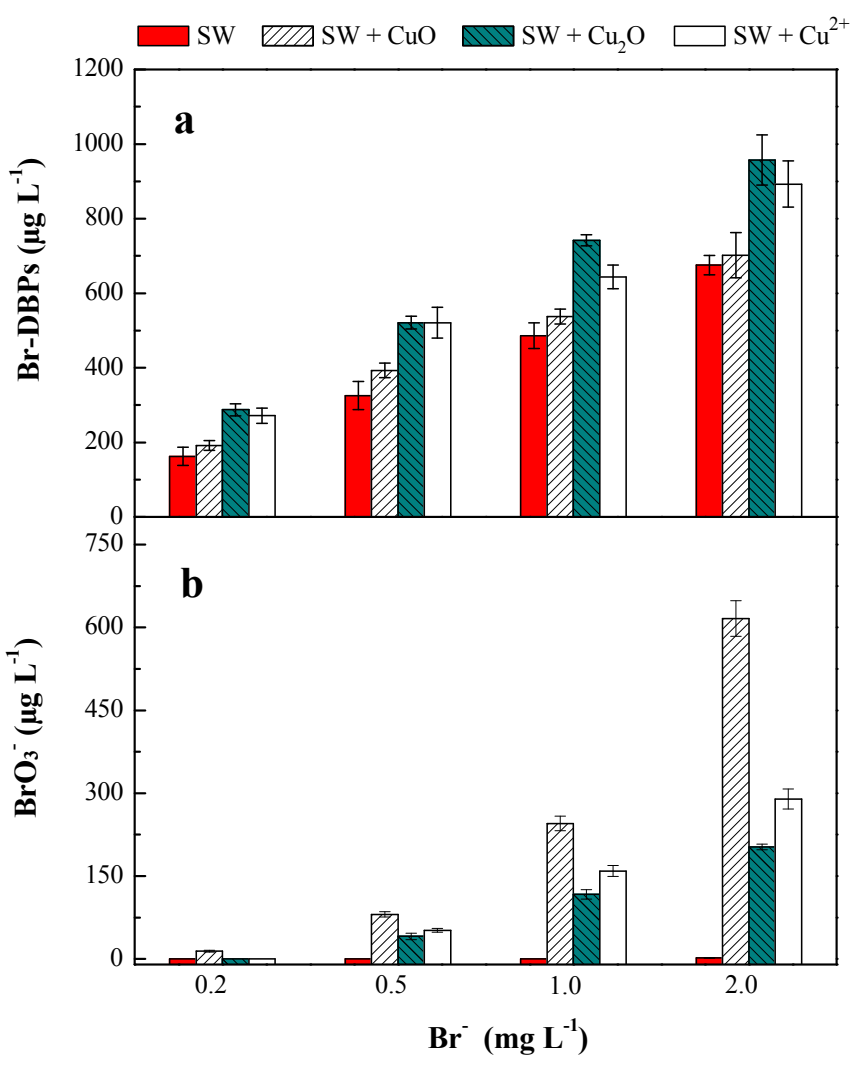

Fig. 6. Effect of $\mathrm{Br}^{-}$concentration on the catalytic formation of $\mathrm{Br}-\mathrm{DBPs}$ (a) and $\mathrm{BrO}_{3}^{-}$ (b) in the SW. Experimental conditions: $\left[\mathrm{Cl}_{2}\right]_{0}=14.2 \mathrm{mg} \mathrm{L}^{-1},[\mathrm{HA}]_{0}=5.0 \mathrm{mg} \mathrm{L}^{-1}$, $[\mathrm{CuO}]=2.0 \mathrm{~g} \mathrm{~L}^{-1},\left[\mathrm{Cu}_{2} \mathrm{O}\right]=0.5 \mathrm{~g} \mathrm{~L}^{-1},\left[\mathrm{Cu}^{2+}\right]=2.0 \mathrm{mg} \mathrm{L}^{-1}, \mathrm{pH}=7.6$, reaction time $=72$ h. Error bars represent the RPDs $(n=2)$.

(DOC) concentration impacted the catalytic formation of $\mathrm{BrO}_{3}^{-}$and Br-DBPs to different extents in the presence of CCPs. The $\mathrm{BrO}_{3}^{-}$ formation was suppressed more significantly with increasing DOC concentration than the Br-DBPs formation. For an instance, at the $\mathrm{Br}^{-}$concentration of $0.5 \mathrm{mg} \mathrm{L}^{-1}$, the enhancement ratios on $\mathrm{Br}$ DBPs formation under $\mathrm{Cu}_{2} \mathrm{O}$ catalysis were $47.4 \%, 44.0 \%$ and $42.9 \%$, while the $\mathrm{BrO}_{3}^{-}$yields under $\mathrm{CuO}$ catalysis were $37.3,40.7$ and $54.6 \mu \mathrm{g} \mathrm{L}^{-1}$, corresponding to the DOC concentrations of 5.34, 4.17 and $2.48 \mathrm{mg} \mathrm{L}^{-1}$ in the MR, JR and NW waters, respectively. It was reported that inorganic ions (e.g., phosphate and sulfate) could be absorbed onto metal oxides (Liu et al., 2013b), thus inhibiting the catalytic activity by blocking the reactive sites. Moreover, inorganic compounds (e.g., ammonia and iodide) could react with bromine (Heeb et al., 2014), resulting in less $\mathrm{HOBr}$ available for the disproportionation and substitution reactions. This result indicates that water matrix had an important impact on the formation of $\mathrm{BrO}_{3}^{-}$ and Br-DBPs in the presence of CCPs.

\section{Conclusions}

This study investigated the catalytic enhancement of CCPs on the formation of $\mathrm{BrO}_{3}^{-}$and $\mathrm{Br}$-DBPs simultaneously during the chlorination of $\mathrm{Br}^{-}$-containing waters. Based on the experimental results obtained, the following conclusions are drawn:

- The oxidant decay and $\mathrm{BrO}_{3}^{-}$formation were enhanced at different degrees in the presence of CCPs, while the presence of HA significantly suppressed the $\mathrm{BrO}_{3}^{-}$formation due to its strong competition for $\mathrm{HOBr}$. 


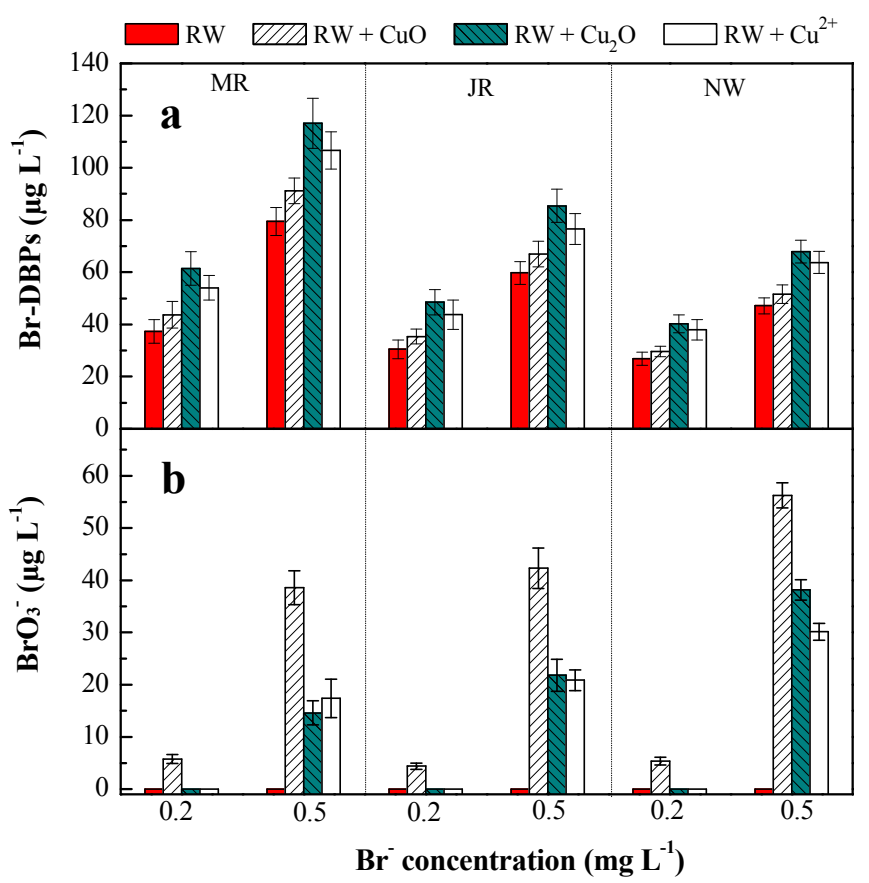

Fig. 7. Catalysis of CCPs on the formation of Br-DBPs (a) and $\mathrm{BrO}_{3}^{-}$(b) in three different real waters (RW) collected from Miyun Reservoir (MR, Beijing), Danjiangkou Reservoir (DR, Hubei), and Beijing No. 9 Waterworks (NW, Beijing). Experimental conditions: $\left[\mathrm{Cl}_{2}\right]_{0}=14.2 \mathrm{mg} \mathrm{L}^{-1},[\mathrm{CuO}]=2.0 \mathrm{~g} \mathrm{~L}^{-1},\left[\mathrm{Cu}_{2} \mathrm{O}\right]=0.5 \mathrm{~g} \mathrm{~L}^{-1},\left[\mathrm{Cu}^{2+}\right]=2.0 \mathrm{mg} \mathrm{L}^{-1}$, $\mathrm{pH}=7.6$, reaction time $=72 \mathrm{~h}$. Error bars represent the RPDs $(n=2)$.

- The $\mathrm{BrO}_{3}^{-}$formation was primarily promoted in the $\mathrm{HOCl}-\mathrm{Br}^{-}-\mathrm{CuO}$ system, while the $\mathrm{Br}-\mathrm{DBPs}$ formation was primarily promoted in the $\mathrm{HOCl}-\mathrm{Br}^{-}-\mathrm{Cu}_{2} \mathrm{O} / \mathrm{Cu}^{2+}$ systems.

- The catalytic formation of $\mathrm{BrO}_{3}^{-}$and $\mathrm{Br}$-DBPs was highly dependent on $\mathrm{pH}$. The degree of enhancement on the Br-DBPs formation became more apparent under an alkaline condition, while the $\mathrm{BrO}_{3}^{-}$formation reached the maximum under a nearly neutral condition.

- The characteristics of the real waters, such as organic compositions, had an important impact on the formation of $\mathrm{BrO}_{3}^{-}$and Br-DBPs in the presence of CCPs.

\section{Acknowledgements}

This study was financially supported by the National Natural Science Foundation (51290281, 51525806, 51408590) and the Ministry of Housing and Urban-Rural Development (2012ZX07404004) of China.

\section{Appendix A. Supplementary data}

Supplementary data related to this article can be found at http:// dx.doi.org/10.1016/j.watres.2016.04.033.

\section{References}

Alvarez-Puebla, R.A., Valenzuela-Calahorro, C., Garrido, J.J., 2004. Retention of Co(II), $\mathrm{Ni}(\mathrm{II})$, and $\mathrm{Cu}(\mathrm{II})$ on a purified brown humic acid. Modeling and characterization of the sorption process. Langmuir 20, 3657-3664.

Beckwith, R.C., Margerum, D.W., 1997. Kinetics of hypobromous acid disproportionation. Inorg. Chem. 36, 3754-3760.

Blatchley, E.R., Margetas, D., Duggirala, R., 2003. Copper catalysis in chloroform formation during water chlorination. Water Res. 37 (18), 4385-4394.

Bougeard, C.M., Goslan, E.H., Jefferson, B., Parsons, S.A., 2010. Comparison of the disinfection by-product formation potential of treated waters exposed to chlorine and monochloramine. Water Res. 44 (3), 729-740.
Chen, J.B., Sun, P.Z., Zhou, X.F., Zhang, Y.L., Huang, C.H., 2015. Cu(II)-catalyzed transformation of benzylpenicillin revisited: the overlooked oxidation. Environ. Sci. Technol. 43, 7003-7009.

Chu, W.H., Gao, N.Y., Krasner, S.W., Templeton, M.R., Yin, D., 2012. Formation of halogenated C-, N-DBPs from chlor(am)ination and UV irradiation of tyrosine in drinking water. Environ. Pollut. 161, 8-14.

Cowman, G.A., Singer, P.C., 1996. Effect of bromide ion on haloacetic acid speciation resulting from chlorination and chloramination of aquatic humic substances. Environ. Sci. Technol. 30, 16-24.

Deborde, M., von Gunten, U., 2008. Reactions of chlorine with inorganic and organic compounds during water treatment - kinetics and mechanisms: a critical review. Water Res. 42 (1-2), 13-51.

Feng, Y., Teo, W.K., Siow, K.S., Tan, K.L., Heieh, A.K., 1996. The corrosion behaviour of copper in neutral tap water. Corros. Sci. 38 (3), 369-385.

Gallard, H., Allard, S., Nicolau, R., von Gunten, U., Croue, J.P., 2009. Formation of iodinated organic compounds by oxidation of iodide-containing waters with manganese dioxide. Environ. Sci. Technol. 43, 7003-7009.

Heeb, M.B., Criquet, J., Zimmermann-Steffens, S.G., von Gunten, U., 2014. Oxidative treatment of bromide-containing waters: formation of bromine and its reactions with inorganic and organic compounds - a critical review. Water Res. 48, 15-42.

Krasner, S.W., Weinberg, H.S., Richardson, S.D., Pastor, S.J., Sclimenti, M.J., Onstad, G.D., Thruston, A.D., 2006. Occurrence of a new generation of disinfection byproducts. Environ. Sci. Technol. 40, 7175-7185.

Kumar, K., Margerum, D.W., 1987. Kinetics and mechanism of general-acid-assisted oxidation of bromide by hypochlorite and hypochlorous acid. Inorg. Chem. 26 (16), 2706-2711.

Lee, Y., von Gunten, U., 2009. Transformation of $17 \alpha$-ethinyl estradiol during wate chlorination: effects of bromide on kinetics, products, and transformation pathways. Environ. Sci. Technol. 43, 480-487.

Li, B., Qu, J.H., Liu, H.J., Hu, C.Z., 2007. Effects of copper(II) and copper oxides on THMs formation in copper pipe. Chemosphere 68 (11), 2153-2160.

Li, B., Liu, R.P., Liu, H.J., Gu, J.N., Qu, J.H., 2008. The formation and distribution of haloacetic acids 9 in copper pipe during chlorination. J. Hazard. Mater. 152 (1) $250-258$.

Liu, C., Croue, J.P., 2016. Formation of bromate and halogenated disinfection byproducts during chlorination of bromide-containing waters in the presence of dissolved organic matter and CuO. Environ. Sci. Technol. 50, 135-144.

Liu, C., von Gunten, U., Croue, J.P., 2012. Enhanced bromate formation during chlorination of bromide-containing waters in the presence of CuO: catalytic disproportionation of hypobromous acid. Environ. Sci. Technol. 46, 11054-11061.

Liu, C., von Gunten, U., Croue, J.P., 2013a. Chlorination of bromide-containing waters: enhanced bromate formation in the presence of synthetic metal oxides and deposits formed in drinking water distribution systems. Water Res. 47 (14), 5307-5315.

Liu, C., von Gunten, U., Croue, J.P., 2013b. Enhanced chlorine dioxide decay in the presence of metal oxides: relevance to drinking water distribution systems. Environ. Sci. Technol. 47, 8365-8372.

Margerum, D.W., Huff Hartz, K.E., 2002. Role of halogen(I) cation-transfer mechanisms in water chlorination in the presence of bromide ion. J. Environ. Monit. 4 (1), 20-26.

Nobukawa, T., Sanukida, S., 2000. The genotoxicity of by-products by chlorination and ozonation of the river water in the presence of bromide ions. Water Sci. Technol. 42 (3-4), 259-264.

Pan, Y., Zhang, X., 2013. Four groups of new aromatic halogenated disinfection byproducts: effect of bromide concentration on their formation and speciation in chlorinated drinking water. Environ. Sci. Technol. 47, 1265-1273.

Pattison, D.I., Davies, M.J., 2004. Kinetic analysis of the reactions of hypobromous acid with protein components: implications for cellular damage and use of 3 bromotyrosine as a marker of oxidative stress. Biochemistry 43, 4799-4809.

Pham, A.N., Rose, A.L., Waite, T.D., 2012. Kinetics of $\mathrm{Cu}(\mathrm{II})$ reduction by natura organic matter. J. Phys. Chem. A 116 (25), 6590-6599.

Qiang, Z.M., Jiang, Y.J., Ben, W.W., Adams, C., Dong, H.Y., 2012. Monitoring free chlorine and free bromine in aquarium seawater treated by ozone. Anal. Methods 4, 3646-3652.

Rice, E.W., 2012. Standard Methods for the Examination of Water and Wastewater American Public Health Association, Washington, D.C.

Richardson, S.D., Thruston, A.D., Rav-Acha, C., Groisman, L., Popilevsky, I., Juraev, O., Glezer, V., Mackague, A.B., Plewa, M.J., Wagner, E.D., 2003. Tribromopyrrole, brominated acids, and other disinfection byproducts produced by disinfection of drinking water rich in bromide. Environ. Sci. Technol. 37, 3782-3793.

Skaff, O., Pattison, D.I., Davies, M.J., 2007. Kinetics of hypobromous acid-mediated oxidation of lipid components and antioxidants. Chem. Res. Toxicol 20 (12), 1980-1988.

USEPA, 2001. National Primary Drinking Water Regulations. Washington D.C.

Xiao, W.Z., Hong, S.K., Tang, Z.J., Seal, S., Taylor, J.S., 2007. Effects of blending on surface characteristics of copper corrosion products in drinking water distribution systems. Corros. Sci. 49 (2), 449-468.

Zhang, H., Andrews, S.A., 2012. Catalysis of copper corrosion products on chlorine decay and HAA formation in simulated distribution systems. Water Res. 46 (8), 2665-2673.

Zhao, Y., Anichina, J., Lu, X., Bull, R.J., Krasner, S.W., Hrudey, S.E., Li, X.F. 2012 Occurrence and formation of chloro- and bromo-benzoquinones during drinking water disinfection. Water Res. 46 (14), 4351-4360. 